\title{
Identity and Belonging in Mudrooroo's Wild Cat Falling
}

Antara Ghatak

South Point School, India

\begin{abstract}
Wild Cat Falling, the rebellious, anti-colonial story by the black Australian author, Mudrooroo, tells us what 'belonging' means in Australia, when one is other than white. Written in an autobiographical mode, Mudrooroo's first novel, Wild Cat Falling is an avant-garde as it presents an interventionist discourse for the first time in the literary history of Australia directed towards opening up the space for self-determined representation by an Aboriginal. The novel retells the continuing entrapment of the Indigenous minority in an inequitable network of social, economic and cultural relationship that they have inherited from British conquest. This paper explores how the issues of identity and belonging make Wild Cat Falling an important interventionist discourse.
\end{abstract}

Keywords: Wild Cat Falling, Mudrooroo, identity, belonging, aboriginal.

Wild Cat Falling traces the story of a young Aboriginal man, who speaking in the first person defines himself throughout the novel using the motif of a cat. The story begins with the unnamed protagonist's release from the prison and the narrative shifts between retrospect and events of the two days he is out of prison, concluding with the Wild Cat's arrest for attempted murder. "Wild Cat" is searching for a place in a society that insists on relegating him to the margin. Marginalized by non-Aboriginal discourse, the protagonist expresses alienation in the city of Fremantle, with no hope for future:

Cars zoom past. Laden trucks lumber and clatter to and to from the wharf. Fremantle is a busy buzzing with movement, everyone but me with somewhere to go. While I was inside some zealous prison worker asked me if I knew where I was going. I said a ticket was put into my hand when I was born, but if it gave a destination, well, time had smudged the ink and so far no collector had come to clear the matter up. (p.31)

Removing the "grey prison uniform of belonging" (p.16), the hero discovers that the mirror outside the institutional walls "reflects a person I take to be myself gazing blank eyed." (p.16). Mudrooroo's hero describes himself as a half-bred delinquent for whom "no one spares a glance" (pg. 30). The institutions like the prison and the boys' homes had almost erased the sense of self for the Wild Cat.

Rupkatha Journal on Interdisciplinary Studies in Humanities (ISSN 0975-2935), Vol 2, No 2, 2010

URL of the Issue: http://rupkatha.com/v2n2.php

URL of the article: http://rupkatha.com/V2/n2/MudroorooWildCatFalling.pdf

(C) www.rupkatha.com 
When the protagonist meets the white student June, on the beach just after his release from prison, he gives a precise idea of his education:

I went to an ordinary school for a couple of years. There I learnt the art of survival against mob rule. Then I got copped for stealing and I was sent to a home where I was educated in the simple techniques of crime and learnt to survive the harshness of Christian charity. In the Noongar camps I learnt the art of being completely unexploitable and of sabotaging every make-believe effort to improve the native's lot. I also learnt to take raw alcohol and raw sex. In jail I graduated in vice and overcame my last illusion about life. Now I know that hope and despair are equally absurd" (p.41)

$\mathrm{He}$ is dislocated both physically and mentally and this dislocation operates to dissolve a potentially balanced image of him. He feels that life can offer him nothing besides despair and resentment from others. In his conversation with June, he makes that clear:

"How old?" she asks.

"Nineteen."

"Practically Methuselah."

"Too old to laugh or cry any more. So old my bones ache."

"That's inactivity," she says. "Look here, you want to get yourself a pair of bathing trunks, get into the sea, run along the sand, lie in the sun."

"And then," I say, "something new will happen for me? A volcano of fresh hope will erupt for me?"

"That's up to you," she says.

I feel the old bitter taste of resentment in my mouth. Nothing ever up to them. Only up to us, the outcast relics in the outskirt camps. The lazy, ungrateful rubbish people, who refuse to co-operate or integrate or even play it up for the tourist trade. Fly-blown descendants of the dispossessed erupting their hopelessness in petty crime." (p.44)

His main aim is to demonstrate a whole range of characteristics, which subvert and resist the integration of dominant Western culture as he had obtained a sense of self in a world where he is eternally imprisoned within and without prison walls, apparently with no hope to escape. When his prison sentence is over, Wild Cat exchanges his "grey uniform of belonging" (p.16) for the "citizen-of-the-world" (p.16) clothes but the exchange is only an attempt to assimilate the Wild Cat, to displace his Aboriginal heritage and replace it with a non-Aboriginal one. However, the protagonist is unable to assimilate himself and wanders over to the beach "looking for a place" (p.37). His talks are full of bravado and hatred. He says, "I suppose I'm not what they call Australian. I'm 
just an odd species of native fauna cross-bred with the migrant flotsam of a goldfield." (p. 69).

The unnamed protagonist is critical about life from childhood. Wild Cat remembers his mother reassuring him that everything would be alright but her words, a representation of hope for future is unable to stand up to the realities of being an Aboriginal in a non- Aboriginal society. When Wild Cat's friends are talking about going to school, he tells them:

"My mum says you've got to go or you can't get on."

"Get on where?" asks the first boy.

"Search me," I say. "Get a job I s'pose."

They look at me with dark and doubtful eyes. (p.12)

These standard clichés of discourse contains a political element: going to school helps an Aboriginal to "get on" but on majority's term.

The white society constantly imbibes in him a strange sense of alienation by demarcating him as an Aborigine. The interaction between the "sophisticated" white woman, June and the protagonist is a case in this point. June, in the novel shows off the central character to her friends, the university crowd and they want to discuss "Aboriginal issues". White cat realizes and so do we that the liberal attitudes of some broadminded Australians are full of superficial sympathy and it counts little in practical terms:

A thin blue stocking kind of girl with big specs and straight short hair pulls up her chair and listens earnestly.

"What I always think," she comes in, "it's not the natives need educating so much. It's the whites."

I guess from the way she looks at me that this is the closest she ever got to an Aboriginal. (p.75)

Mudrooroo's hero expresses numbness, the same kind of alienation in his relationship with women. He sees many sexual interactions through the power relations without love. Every time he makes love or wants to, all he seems to notice are the physical attributes of his mate and then he is full of remorse. He even goes this far to make an analogy between sexual act and rape because he wishes to be unmoved by everything, "like a god." (p. 90). Important in this background is his mother. Wild Cat is unable to come to terms with his mother; he tries to be tough to her as she had been to her own Aboriginal relatives. The majority discourse has compelled his mother to teach her to live white and learn to think white man's mind, by making the Aboriginal past unacceptable. While thinking of his past he remembers: 
Mum's always telling me how lucky we are to have this place and her widow's pension to keep us on. She had to put a fight to convince the authorities that she had been legally married to a white man and wanted to go on living white. (pp. 8-9)

By collaborating with the whites, Wild Cat's mother has displaced her own sense of belonging and has forced her son to be a mere subject of the white society. He could never forgive his mother for that and he is full of hatred even when he learns that she is in her deathbed. At the end of the novel as he comes to know that his mother has come back to the Noongar camp and is dying, he observes:

So now she has gone back to die with them and be buried in that back part of the cemetery in a nameless Noongar grave. Serves her right. She had it coming to her, pretending to be better than the rest of them, keeping me away from them, giving me over like a sacrificial offering to the vicious gods of the white man's world.(p. 123)

This inability to connect with the mother has its repressions in Wild Cat's relations with other women.

Notions of displacement and loss predict absence. For the protagonist of the novel, one of the most significant absences is that of a father. Primarily the Wild Cat character suffers from the loss of identity because of an absent white father. His mother's internalized colonization culminates in her rejection of her Aboriginal heritage and her desire to pass on as a white woman required that she should engage herself in a relationship with Mr Willy, a white man:

$\mathrm{He}$ [Mr Willy] was pretty old but he was white and earned a decent enough crust from his wood-cutting. He didn't live with us, just dropped in and stayed the night sometimes. He found this place for us and got us the furniture. Mum was proud and respectable. (p.9)

As a child Wild Cat tried to ascribe the role of a father to his mother's boyfriend, Mr Willy. Importantly the most euphoric, least nihilistic moment in Wild Cat Falling is the part in which Mr Willy, who calls him "son", takes the protagonist as a child to a wood for a trip:

"Get a good view from up there?" Mr Willy asked.

"The whole world," I say.

"Hmm," says Mr Willy and shakes his white head.

"The world's big place, son."

"I know," I say. And I feel it is a good and wonderful world. (p.36) 
Happiness and belonging are tied up with the creation of a father figure. However, the symbolic overtone of this passage undermines this happiness. Willy negates the euphoria with a shake of his "white head", delineating the limits of the dominant culture.

The young Wild Cat at every turn of life realizes that the European world would always push him to the fringes, would always usurp his rights. He feels suffocated and he flings himself out of the door into the lanes:

A trumpet blares a cynical laughing tune as I run out into the lane. The buildings sway inwards on either side. The ground withers under my feet. I look up and the sky is blurred with reeling stars. Nothing stable and true in all universe. The footpath rises and sends me sprawling on hands and knees. I get up and struggle on....Like ashes, like sand, like life...no refuge anywhere. (p.93)

Near the end, the Wild Cat finally finding no space for him in the white dominated society exhibits anger, disrespect for judicial laws that exists only to reconcile him to the prescribed norms of the society. He shoots a police officer and flees form the police. He realizes how he had always accepted his marginality all throughout his life and he was tired of it.

The dejected, dislocated Wild Cat is ultimately offered an alternative discourse, alternative reality he was search of through the Cat and the Crow dream which reflects the intuitive process of Indigenous realities that stems from the cultural phenomena of Dreaming. Mudrooroo has noted that the notion of Dreaming indicates "a psychic state in which or during which contact is made with the ancestral spirits [...] a complex metaphysical and spiritual concept for which there is simply no adequate English rendering" [Mudrooroo, p.41]. This phenomenon of Dreaming is experienced by the character in the form of recurring dream that is forgotten on awakening. In this dream, the protagonist sees himself in the form of a cat with the wings of a crow. He feels terror as he reaches for the moon only to plunge in fear towards the earth, "Falling, falling. Plunging and twisting out of the sky. Down and down the dark ground rising up..." (p.124). It apparently signifies his desire to disengage from a colonial reality, which demands, he must be marginalized. It also signifies the importance of myth and magic, the unconscious to the Aboriginal society. Later, it is only by identifying the secret world, the tradition, the Wild Cat is able to shape a space for himself.

The old Aboriginal, the "magic man as old as the sky" (p.35), offers him the ultimate illumination. He takes care of the bewildered young man in the bush during his attempted escape from the police. He plays the role of the absent father during the moment of crisis and stands as a connection between the Wild 
Cat and the Noongar community. The old rabbiter interprets the Cat/Crow dream and explains that it is not a nightmare but a song- one given to the protagonist by his ancestors, which has been passed from one generation to another. When the young man says, "I have a dream," (p.127), the "blackfella" says:

"Might be your granny teach it when you been a little fella. Desert country." He makes a pointing motion with his chin.

"I don't remember any grandmother."

"Good woman," he says, "properly blackfella. No white blood."

"My sister," he says simply. He nods. "She give you that song might be."

I want to go, but something holds me here.

"What does it mean, anyway?"

"Belonging dreaming time," he says. "That cat want to live a long time like the old crow. 'How you don't die?' he asks. 'I fly up high, high up to the moon. I get young up there, then come down.' That cat look sorry then. 'I got no wings.' Then the old crow laugh carr-carr. 'You don't need no wings. You can fly all right. You try now.' See?"

The old voice trails on, but now I have remembered the dream. It has been in some secret part of my mind to which he has given me a key. ( $p$. 127)

This illumination connects him with his community. The Wild Cat returns to the spiritual roots of Aboriginality and for the first time he belongs. The old Aborigine names him:

Jessie Dugan's boy [...] I know your mummie and your grandmummie. That old woman, she had been my tribal sister you know. She call me brother, only your mummie can't call me uncle any more. She got to forget all that in the mission school." (p.121)

Instead of being alone, as he has been throughout the novel, "Jessie Dugan's boy" now has a community where he can belong. This communion re-inscribes a place for him, establishes links of tradition and kinship. The old man's song intimates him with the bush, with his land and the past. He does not speak Aboriginal language but he feels as though he recognizes the song the old man sings:

He begins to sing again, softly, like the humming of a bee, then the words shape on his lips and breaks off.

"You know that song, son."

"Suppose I heard it somewhere before," I say.

"You dream it," he says. "It belong your country."

"I haven't got a country," I say. "I don't belong anywhere." 
"You can't lose it," he says. "You go away, but you keep it here." He claps his hand under his ribs. "Inside. You dream that place and that song too. I hear you sing it in your sleep." (p.126)

The old Aboriginal places him at the center by providing him with an illumination, by imparting lessons that tell about Aboriginal generosity that lies in sharp contrast with European greed and hypocrisy. The song that the old man sings becomes the mantra, which "Jessie Dugan's boy" can chant as long as he lives. The Europeans cannot understand the old man's song and this time the "whites" and not the Wild Cat are the people who do not belong. When the unnamed protagonist leaves the old man's camp as "Jessie Dugan's boy", he feels he wants to live more with a renewed sense of belonging. He asserts, "I want to live more than I ever knew before. I even feel I might know just a little how to live." (p.130)

\section{Works Cited}

Archer-Lean, Clare. Cross-Cultural Analysis of The Writings Of Thomas King And Colin Johnson (Mudrooroo). New York: The Edwin Press, 2006.

Ashcroft, Bill, Gareth Griffiths and Helen Tiffin, eds. Key Concepts in Post-Colonial Studies London: Routledge, 1995.

Goodwin, Ken. A History of Australian Literature. London: Macmillan, 1986.

Lefebvre, Henri. Production of Space. Trans. D. Nicholas-Smith. Oxford: Blackwell, 1991.

Mitchell, Adrian. The Oxford Literary History of Australian Literature. Melbourne: Oxford University Press, 1981.

Mudrooroo. Writing From the Fringe: A Study of Modern Aboriginal Literature. (First published under the name Mudrooroo Narogin). South Yarra, VIC: Hyland House, 1990.

Mudrooroo, Us Mob: History, Culture, Struggle; An Introduction to Indigenous Australia. Sydney: Angus \& Robertson, 1995.

Mudrooroo, (originally published under name Johnson, Colin). Wild Cat Falling. Sydney: Angus and Robertson, 1965.

Oboe, Annalisa, ed. Mongrel Signatures -Reflections on the Work of Mudrooro. New York: Rodopi, 2003. 
Shoemaker, Adam. Mudrooroo: A Critical Study. Sydney: Pymble, NSW: Angus and Robertson, 1993.

Webb, Hugh. "The Works of Mudrooroo Narogin (Colin Johnson): 31 Years of Literary Production, 1960-1991", Span, no. 33, May 1992.

\section{Internet Sources}

http://www.mudrooroo.com/4547html.

http://www.literatureclassics.com/essays/817.

http://auslit.com/a/mudr/index.html.

Antara Ghatak teaches in South Point School. Email: antaraghatak@gmail.com 